\title{
Pasting Properties of Acha-Green Banana Composite Flour Fortified with Cowpea Flour and Quality Evaluation of Gluten-Free Biscuit Made from the Blends
}

Inyang UE*, Nwabueze SO

Department of Food Science and Technology, University of Uyo, Uyo Akwa Ibom State, Nigeria

Article History

Received: 18.09 .2020

Accepted: 09.10.2020

Published: 17.10 .2020

Journal homepage:

https://www.easpublisher.com/easjnfs

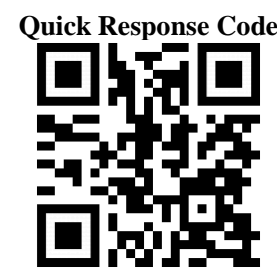

Abstract: The needs to limit wheat importation into Nigeria and to develop nutritious products for celiac patients have necessitated the search for alternative flour sources to partially or wholly replace wheat in bakery products preparation. The present study was aimed at evaluating the effects of substituting $70 \%$ acha -30 green banana composite flour with $0,10,20,30,40$ and $50 \%$ cowpea flour on the pasting properties of the flour blends and on the physical properties, nutrient composition and sensory characteristics of biscuits made from the flour blends. The unfortified flour served as the control sample. The result showed that all the parameters evaluated varied with the proportion of cowpea flour incorporation. The peak, trough, final and setback viscosities significantly $(p<0.05)$ decreased while the peak time and peak temperature increased with increase in cowpea flour substitution. Biscuit made from unfortified flour exhibited lower thickness but higher diameter and spread ratio than biscuits made from cowpea substituted flours. The protein, fat, crude fibre, calcium, iron and zinc contents in the biscuits progressively increased from $9.57-17.41 \%, 10.86-12.01 \%, 1.92-2.14 \%, 31.79-43.95 \mathrm{mg} / 100 \mathrm{~g}, 3.01-4.58 \mathrm{mg} / 100 \mathrm{~g}$ and $1.95-3.23 \mathrm{mg} / 100 \mathrm{~g}$ respectively with increase in cowpea flour substitution. Conversely, the ash, carbohydrate and potassium contents in the biscuits progressively decreased from $2.48-2.13 \%, 75.17-66.14 \%$ and $78.84-56.90 \mathrm{mg} / 100 \mathrm{~g}$ respectively with increase in cowpea flour substitution. The sensory mean scores by the panellists for the attributes evaluated showed variations among the biscuit samples. Biscuits produced from blend of $80 \%$ acha - green banana composite flour and $20 \%$ cowpea flour was the most preferred by the panellists in terms of taste, aroma, texture, and overall acceptability. Utilization of composite flour from these locally grown crops will reduce wheat importation, increase their utilization, enhance the nutritional value and provide biscuit variety for celiac patients.

Keywords: Acha-green banana composite flour, cowpea flour, fortification, gluten-free biscuit, nutrient composition, pasting properties, physical characteristics, sensory attributes.

Copyright () 2020 The Author(s): This is an open-access article distributed under the terms of the Creative Commons Attribution 4.0 International License (CC BY-NC 4.0) which permits unrestricted use, distribution, and reproduction in any medium for non-commercial use provided the original author and source are credited.

\section{INTRODUCTION}

Biscuits made from wheat flour are one of the most widely consumed bakery products around the world due to their relatively low cost, varied taste and long shelf life $[1,2]$. However, for a tropical country like Nigeria with unfavourable climatic condition for profitable wheat production, it is not economical to continue with wheat importation to augment local production because of its adverse effect on the nation's foreign reserve. Also, consumption of wheat products usually triggers celiac disease in genetically predisposed individuals due to gluten that is present in wheat, and this seriously impair intestinal absorption and can lead to severe malnutrition [3]. Production of gluten-free biscuit from locally grown crops is therefore desirable to meet the need of gluten intolerant individuals and to also reduce the amount spent on wheat importation.

Acha (Digitaria exilis), commonly referred to as hungry rice or fonio is one of the cereal grains widely cultivated in the Northern part of Nigeria but is underutilized despite the nutritional and health benefits associated with its consumption. Acha is naturally and always consumed as whole grain and traditionally used in the preparation of "tuwo" and "kunun" or milled and used as thickener in soups. The use of acha as whole grain makes it an excellent source of dietary fibre. According to Kamran et al. [4], food products that are high in dietary fibre are useful in the prevention and treatment of constipation, cardiovascular diseases and hypertension. Acha is composed of polysaccharides $(75 \%)$, protein $(8-10 \%)$, about $1 \%$ fat content and is a good source of calcium and phosphorus [5]. Although, 
high in carbohydrate, it is reported to exhibit low glycemic index [6], which makes it good for diabetic individuals. Its protein is uniquely rich in methionine and cystine [7, 8], that are crucial for proper heart functioning and nerve transmission [9]. Its use in composite flour formulation can add value to the crop and also increase its utilization.

Banana (Musu spp.) is a popular and leading fruit crop which grows in tropical countries [9]. As a climacteric fruit, it is always harvested at mature green stage to reduce postharvest losses [10]. The mature green fruit is low in protein and fat contents, high in starch content and is rich in bioactive compounds with high antioxidant potential and anti-tumoral activities $[10,11]$. Processing of green banana into flour helps to add value to the crop in terms of reducing waste and loss during the production chain, improve sustainability, and capture some of the nutritional benefits that are lost on ripening [12]. Green banana flour is high in resistant starch (about $74 \%$ of its composition) and may be used for functioning food purposes in controlling glycemic indexes, cholesterol, gastric fullness, intestinal regularity, and production of short-chain fatty acids that can prevent cancer in intestinal cells [13]. Scarminio et al. [14] reported that dietary use of green banana flour constitutes an important dietary supplement and complementary medicine product for bowel disease as indicated in an in vivo study.

Consumption of large quantities of products made from acha and green banana flours could mitigate hunger but may not provide vital nutrients required for proper sustenance since they are high in carbohydrate but low in protein. Addition of small quantity of legume such as cowpea flour in their formulation would enhance the nutritional value of the product. Cowpea (Vigna unguiculata) commonly called beans is widely cultivated and consumed as a whole or part of a meal in Nigeria. It is considered as a cheap source of protein for people who have limited access to proteins from conventional animal sources such as meat, milk and egg [15]. The protein content in cowpea ranges from $18-$ $25 \%$ [16]. The protein contains appreciable amount of lysine and tryptophan but is deficient in methionine and cystine when compared with animal protein [17]. This makes cowpea protein a great complement to acha protein that is deficient in lysine but high in methionine and cystine. The present study was aimed at assessing the effect of fortifying composite of acha - green banana flour with cowpea flour on the pasting properties of the flour blends and quality characteristics of gluten - free biscuit made from the blends.

\section{Materials ANd Methods Materials Procurement}

Mature green banana, cowpea, butter, salt, egg, powdered milk, baking powder and nutmeg were purchased from Akpan Andem Market, Uyo, Akwa
Ibom State, Nigeria. Acha was purchased from oil mill market in Port Harcourt, Rivers State, Nigeria.

\section{Materials Preparation Preparation of Acha Flour}

Acha flour was prepared following the method described by Ayo and Okoye [18]. The grains were manually sorted to remove unwanted materials, sieved and washed in clean water to remove dust, chaff and other foreign materials (by decanting them as they float on top of the water). Stones were also removed by sedimentation during washing. The water was drained off using a sieve and the grains dried in a hot air oven (Model PP, $22 \mathrm{US}$, Genlab, England) at $50^{\circ} \mathrm{C}$ for $6 \mathrm{hr}$, milled using attrition mill, sieved through $0.20 \mathrm{~mm}$ aperture screen and packaged in air tight plastic container for subsequent use.

\section{Preparation of Green Banana Flour}

Green banana flour was prepared using the method described by Anggraeni and Saputra [19] with slight modification. Green banana fruits were individually plucked from banana hands, washed in clean water, blanched in hot water $\left(100^{\circ} \mathrm{C}\right)$ for 10 minutes, cooled and peeled using a stainless knife. The peeled bananas were sliced ( $5 \mathrm{~mm}$ thickness) and soaked in $0.20 \%$ solution of sodium metabisulfite for $5 \mathrm{~min}$. The solution was drained off and the slices dried at $50^{\circ} \mathrm{C}$ in a hot air oven (Model PP, 22 US, Genlab, England) to constant weight. The dried slices were milled using hammer mill, sieved to pass through $0.20 \mathrm{~mm}$ aperture screen and packaged in air tight plastic container for subsequent use.

\section{Preparation of Cowpea Flour}

Cowpea flour was prepared using the method described by Akosua et al. [20]. The cowpea beans were manually sorted to remove unwholesome ones and foreign materials. The sorted beans were soaked in water for 12 hours, blanched in hot water $(1: 3 \mathrm{w} / \mathrm{v})$ at $100^{\circ} \mathrm{C}$ for $5 \mathrm{~min}$, cooled and dehulled manually by rubbing between the palms. The dehulled beans were dried in hot air oven $50^{\circ} \mathrm{C}$ to constant weight, milled, sieved to pass through $0.20 \mathrm{~mm}$ aperture screen and packaged in air tight plastic container for subsequent use.

\section{Formulation of Composite Flour}

In pre-trials, an addition of $30 \%$ green banana flour to $70 \%$ acha flour provided acceptable biscuit. Based on this finding, composite of $70 \%$ acha and $30 \%$ green banana flours was supplemented with $0,10,20$, 30, 40 and 50\% cowpea flour and used for the main experiment. The $100 \%$ composite of $70 \%$ acha and $30 \%$ banana flours served as control sample. The formulated flour blends were analyzed for pasting properties and the remaining portions used for the production of biscuits. 


\section{Ingredients Formulation and Biscuit Production:}

The ingredients formulation reported by Poopola et al. [21] was adopted for the preparation of biscuits. The ingredients composed of flour $(250 \mathrm{~g})$, butter $(63 \mathrm{~g})$, sugar $(63 \mathrm{~g})$, salt $(1 \mathrm{~g})$, whole egg $(20 \mathrm{ml})$, powdered milk $(5 \mathrm{~g})$, nutmeg $(1.5 \mathrm{~g})$ and baking powder (1g).

The biscuits were produced following the creamy method described by Man et al. [1]. The butter and sugar were creamed together until light and fluffy. Egg and powdered milk were added, while mixing continued. Flour, baking powder, ground nutmeg and salt were added to the cream and mixed in a bowl mixer to form dough. The dough was removed from the bowl and kneaded on a flat surface, rolled to a uniform thickness using a rolling pin, cut to a uniform diameter with the aid of a cutter and baked at $180^{\circ} \mathrm{C}$ for 17 minutes. The baked products were cooled, packaged in high density polyethylene, labeled and used for various determinations.

\section{Methods OF ANALYSIS}

\section{Pasting Properties Determination:}

Pasting properties of the flour samples were determined using a Rapid Visco Analyzer 3C (RVA, Model 3C, Newport Scientific PTY Ltd, Sydney, Australia)[75]. Three grams (3g) of each sample was weighed into a canister and $25 \mathrm{ml}$ of distilled water was dispensed into the canister containing the sample and mixed thoroughly to form slurry. The canister with the slurry was fitted into the RVA as recommended. The slurry was heated from $50^{\circ} \mathrm{C}$ to $95^{\circ} \mathrm{C}$ with a holding time of $2 \mathrm{~min}$ and cooled to $50^{\circ} \mathrm{C}$ with a holding time of $2 \mathrm{~min}$. The rates of heating and cooling were done at a constant rate of $11.25^{\circ} \mathrm{C} / \mathrm{min}$. The peak viscosity (PV), trough viscosity (TV), breakdown viscosity (BDV), final viscosity (FV), setback viscosity (SBV), peak time and pasting temperature were obtained from the pasting profile with the aid of thermocline for windows software connected to a computer generating the data from the RVA unit [22]. The viscosities were expressed in terms of Rapid Visco Units (RVU).

\section{Determination of physical Characteristics of Prepared Biscuits:}

The biscuit diameter was determined by placing six biscuits horizontally (edge to edge) in a row and the diameter was measured with a digital vernier caliper with $0.01 \mathrm{~mm}$ accuracy [1]. The mean value was recorded as the diameter of the biscuits. Thickness of biscuit was determined by stacking six biscuits, one on top of another and the average thickness was taken, using digital vernier caliper with $0.01 \mathrm{~mm}$ accuracy [1]. The mean value was recorded as the thickness of the biscuit. The spread ratio was calculated as the average diameter/thickness [23].

\section{Determination of Nutrient Composition of Prepared} Biscuits

Moisture, crude protein, fat, ash and crude fibre contents in the prepared biscuits were determined using the methods described in AOAC [24]. Carbohydrate was calculated by subtracting from 100 the sum of protein, fat, ash and crude fibre [25]. Caloric value was calculated using Atwater factor formula [26]. Mineral contents $(\mathrm{Ca}, \mathrm{K}, \mathrm{Fe}$ and $\mathrm{Zn}$ ) were determined using atomic absorption spectrophotometer (UNICAM Model 939, UK) as described in AOAC [24].

\section{Sensory Evaluation of the Prepared Biscuits}

The biscuits produced from different flour blends were subjected to sensory evaluation performed by 30 semi-trained panels of judges. All panellists were regular consumers of biscuits and were familiar with sensory quality attributes of biscuits. Sensory parameters assessed were colour, taste, aroma, texture, crispness and overall acceptability on a 9-point hedonic scale ranging from 1 (dislike extremely) to 9 (like extremely) [27]. The samples served were coded with three digit random numbers and presented in identical containers. The panellists were asked to rinse their mouth with water provided between the samples to avoid carry over effect. Questionnaire for entering scores was provided to the panel members.

\section{Statistical Analysis}

Data obtained were subjected to a one-way Analysis of Variance (ANOVA) using the software statistical package for social sciences (SPPS) version 18 (SPPS, Inc, Chicago, USA) to determine significant difference at $\mathrm{p}<0.05$. Means were separated using Duncan's Multiple Range Test (DMRT).

\section{ReSUlts AND DiscusSiON}

\section{Effect of the Treatment on Pasting Properties of the} Flour Samples:

Pasting properties of starch - based food refer to the changes that occur in the food as a result of application of heat in the present of water. These properties are indicative of certain parameters of flour quality such as starch swelling, gelatinization and retrogradation [28]. Determination of these properties in composite flours is of significant importance as they are known to affect texture, stability, digestibility and end use of starch-based food commodities [29-31]. It is usually used as an index for predicting the ability of starch-based flour to form a gel or viscous paste when subjected to heat application. Pasting properties are dependent on the rigidity of starch granules, with consequent effect on the granule swelling potential and the amount of amylose leaching out in the solution [32].

The effect of fortifying acha - green banana composite flour with $0-50 \%$ cowpea flour on the pasting characteristics of the flour blends is presented in Table 1. 
Table-1: Pasting properties of acha-green banana composite flours fortified with cowpea flour

\begin{tabular}{|l|c|c|c|c|c|c|}
\hline \multirow{2}{*}{ Pasting Properties } & \multicolumn{6}{|c|}{ Blending ratios (acha-banana flour: cowpea flour) } \\
\cline { 2 - 7 } & 100.00 & 90.10 & 80.20 & 70.30 & 60.40 & 50.50 \\
\hline Peak viscosity (RVU) & $886.00^{\mathrm{a}} \pm 2.13$ & $675.00^{\mathrm{b}} \pm 1.51$ & $548.00^{\mathrm{c}} \pm 4.02$ & $412.00^{\mathrm{d}} \pm 3.40$ & $323.00^{\mathrm{e}} \pm 2.51$ & $237.00^{\mathrm{f}} \pm 4.63$ \\
\hline $\begin{array}{l}\text { Trough viscosity } \\
\text { (RVU) }\end{array}$ & $798.00^{\mathrm{a}} \pm 3.16$ & $632.00^{\mathrm{b}} \pm 5.09$ & $527.00^{\mathrm{c}} \pm 2.11$ & $401.00^{\mathrm{d}} \pm 4.09$ & $308.00^{\mathrm{e}} \pm 3.20$ & $219.00^{\mathrm{f}} \pm 2.90$ \\
\hline $\begin{array}{l}\text { Breakdown viscosity } \\
(\mathrm{RVU})\end{array}$ & $88.00^{\mathrm{a}} \pm 5.02$ & $43.00^{\mathrm{b}} \pm 2.65$ & $21.00^{\mathrm{c}} \pm 6.20$ & $11.00^{\mathrm{f}} \pm 2.18$ & $15.00^{\mathrm{e}} \pm 4.32$ & $18.00^{\mathrm{d}} \pm 3.11$ \\
\hline Final viscosity (RVU) & $1,300.00^{\mathrm{a}} \pm 3.68$ & $984.00^{\mathrm{b}} \pm 4.10$ & $830.00^{\mathrm{c}} \pm 1.95$ & $626.00^{\mathrm{d}} \pm 3.62$ & $497.00^{\mathrm{e}} \pm 3.50$ & $375.00^{\mathrm{f}} \pm 5.08$ \\
\hline $\begin{array}{l}\text { Setback viscosity } \\
\text { (RVU) }\end{array}$ & $502.00^{\mathrm{a}} \pm 4.19$ & $352.00^{\mathrm{b}} \pm 3.52$ & $303.00^{\mathrm{c}} \pm 2.46$ & $225.00^{\mathrm{d}} \pm 4.31$ & $189.00^{\mathrm{e}} \pm 5.18$ & $156.00^{\mathrm{f}} \pm 2.75$ \\
\hline Peak Time (min) & $5.67^{\mathrm{d}} \pm 0.00$ & $6.00^{\mathrm{c}} \pm 0.01$ & $6.33^{\mathrm{b}} \pm 0.01$ & $6.80^{\mathrm{a}} \pm 0.02$ & $6.87^{\mathrm{a}} \pm 0.00$ & $6.87^{\mathrm{a}} \pm 0.00$ \\
\hline $\begin{array}{l}\text { Pasting Temperature } \\
\left({ }^{\circ} \mathrm{C}\right)\end{array}$ & $87.30^{\mathrm{d}} \pm 0.02$ & $88.70^{\mathrm{d}} \pm 0.01$ & $89.60^{\mathrm{c}} \pm 0.00$ & $90.80^{\mathrm{c}} \pm 0.04$ & $92.00^{\mathrm{b}} \pm 0.03$ & $93.20^{\mathrm{a}} \pm 0.01$ \\
\hline
\end{tabular}

Each value is the mean of triplicate determinations. Means on the same column with different superscripts are significantly different at $\mathrm{P}=0.05$.

The result revealed that there were significant $(p<0.05)$ differences in the pasting profile of the flour samples. The peak viscosity (PV), trough viscosity (TV), breakdown viscosity (BDV), final viscosity (FV) and setback viscosity (SBV) significantly $(\mathrm{p}<0.05)$ decreased while the peak time and peak temperature increased progressively with increase in cowpea flour substitution.

The peak viscosity is the maximum viscosity reached during or soon after the heating aspect of the test [33]. It reflects the ability of starch granules to swell freely before their physical breakdown during heating and is related to the water binding capacity of starch [34]. The PV provides an indication of viscous loads likely to be entered during mixing and is often correlated with the final product quality [35]. The PV of the samples decreased significantly $(\mathrm{p}<0.05)$ from 886.00RVU for $100 \%$ acha - banana composite flour (control) to $237.00 \mathrm{RVU}$ for $50 \%$ cowpea flour substituted sample. The reduction of PV values with increased in cowpea flour substitution may be attributed to lower starch and higher protein contents in cowpea flour than in acha - banana composite flour which caused a low gelatinization and swelling index. Tan and Corke [36] reported that high protein content is negatively correlated to peak viscosity and hot paste viscosity. According to Shittu et al. [37], the higher the $\mathrm{PV}$, the higher the swelling index, while low PV is indicative of higher solubility as a result of starch degradation or dextrinization. The PV result of this study is in harmony with the reports by Tharise et al. [38], Ouazib et al. [39] and Ohizua et al. [40] for soybean, chickpea and pigeon pea fortified flours respectively. The differences observed in the PV of the samples indicate that there were differences in the rate of water absorption and starch granule swelling during heating [28]. The relatively lower PV values in cowpea flour substituted samples than in the control sample is an indication that the cowpea fortified flours may be suited for products that require low gel strength and elasticity [41].
The trough viscosity (TV) otherwise known as holding strength viscosity is the point at which the viscosity reaches its minimum during either heating or cooling processes and measures the ability of the paste or gel formed to withstand breakdown during cooling $[42,43]$. The TV decreased significantly $(\mathrm{p}<0.05)$ from 798.00RVU for the control sample to 219.00RVU for the $50 \%$ cowpea flour substituted sample. This may be attributed to lower starch content in cowpea flour than in acha-banana composite flour. According to Badejo et al. [44], the lower the TV value, the more stable is the starch gel. Similar results have been reported by Ohizua et al. [40] and Julianti et al. [45] for composite flours with legume flour inclusion.

Breakdown viscosity (BDV) is the difference between the peak viscosity and trough viscosity and measures the ability of the flour to withstand heating and shear stress during cooking [29, 46]. The BDV decreased significantly $(\mathrm{p}<0.05)$ as a result of cowpea flour substitution ranging from 88.00RVU for the control sample to $11.00 \mathrm{RVU}$ for the $30 \%$ cowpea flour substituted sample and then increased to 15.00RVU and $18.00 \mathrm{RVU}$ for the $40 \%$ and $50 \%$ cowpea flour substituted samples respectively. High BDV is associated with increased susceptibility of flour to withstand heating and shear stress during cooking [33]. Bakare et al. [46] also noted that lower BDV is an indication of higher paste stability. The lowest BDV exhibited by the $30 \%$ cowpea flour substituted sample is an indication that it had the highest paste stability while the control sample with the highest BDV value had the least paste stability.

The final viscosity (FV), a parameter commonly used to determine a sample's ability to form a viscous paste or gel after cooking and cooling [35, 47], decreased significantly $(\mathrm{p}<0.05)$ from $1,300.00 \mathrm{RVU}$ for the control sample to 375.00RVU for the $50 \%$ cowpea flour substituted sample. With increasing level of cowpea flour substitution, the relative content of starch in the sample decreased leading to reduction in the final viscosity. According to 
Tester and Morrison [48], final viscosity depends on the starch content, amylose, amylopectin, as well as amylose/amylopectin ratio. The FV result obtained in the present study is in harmony with the reports by Tharise et al. [38], Ouazib et. al. [38], Ohizua et al. [40] and Ratnawata et al. [49] for composite flours with legume flours inclusion.

The values of the setback viscosity (SBV) act as indicator for the starch retrogradation/syneresis during storage/thawing and the texture of starch-based food products is directly dependent on setback viscosity $[40,50]$. The SBV of the flour samples significantly $(p<0.05)$ decreased with increase in the proportion of cowpea flour substitution ranging from 502.00RVU for the unfortified acha-banana composite flour (control sample) to $156.00 \mathrm{RVU}$ for the $50 \%$ cowpea flour substituted sample. The reduction in SBV with increase in the level of cowpea flour substitution indicates reduction in the textural characteristics of the samples since SBV has been correlated with texture of various food products [29, 50, 51]. Peroni et al. [52] reported that flours with low setback viscosity may have low values of amylose which have high molecular weight. Other authors [38, 39, 45, 49] had similarly reported of reduction of setback viscosity as a result of incorporation of legume flours in composite flour formulations. Low setback value is an indication that the starch has a low tendency to retrograde or undergo syneresis during freeze thaw cycle $[53,54]$. The SBV result indicates that the control sample would have higher tendency to retrograde than the cowpea flour fortified blends.

Peak time is the time in minutes at which the peak viscosity occurred and it is a measure of the cooking time of the flour [29]. The peak time increased with increase in the cowpea flour substitution ranging from $5.67 \mathrm{~min}$ for the control sample to 6.87 for $40 \%$ and $50 \%$ cowpea flour substituted samples. Low peak time is indicative of the sample's ability to cook fast.
This implies that the unfortified flour would cook faster than the cowpea flour fortified blends.

Pasting temperature is an indicator of minimum energy (minimum temperature) required to cook starch containing food products [23, 50]. It is assumed to be the beginning point of starch gelatinization and a point where viscosity starts to increase [50]. The pasting temperature progressively increased with increase in cowpea flour supplementation ranging from $87.30^{\circ} \mathrm{C}$ for the control sample to $93.20^{\circ} \mathrm{C}$ for the $50 \%$ cowpea flour substituted blend. A high pasting temperature usually indicates high water binding capacity, high gelatinization tendency and low swelling property of starch-based flour due to high associative forces between starch granules [33]. Pasting temperature depends on the size of starch granules in the flour, small starch granules are more resistant to rupture and loss of molecular order [55]. It is evident from the pasting temperature values that the control sample could be said to be more sensitive to heat treatment with less energy consumption, thereby saving time and cost than the cowpea flour fortified blends.

\section{Effect of the Treatment on Physical Characteristics of Prepared Biscuits:}

The effect of substituting acha - green banana composite flour with different levels of cowpea flour on the physical characteristics of biscuits prepared from the flour blends is shown in Table 2 . The result showed that the treatment affected the thickness, diameter and spread ratio of the biscuits. Biscuit diameters were reduced, while the thickness increased as a result of cowpea flour incorporation. Similar results were reported by Tiwari et al. [56], Kohajdová et al. [57] and Man et al. [1] for biscuits with pigeon pea, pea and soy flour incorporation respectively. The biscuit prepared from unfortified flour recorded the least thickness $(3.68 \mathrm{~cm})$ and the highest diameter $(4.31 \mathrm{~cm})$ while the $50 \%$ cowpea flour fortified biscuit recorded the highest thickness $(4.09 \mathrm{~cm})$ and the least diameter $(4.16 \mathrm{~cm})$.

Table-2: Physical properties of biscuit made from composite of acha and green banana flours fortified with cowpea flour

\begin{tabular}{|l|c|c|c|c|c|c|}
\hline & \multicolumn{5}{|c|}{ Blending ratios (acha-banana flour: cowpea flour) } \\
\cline { 2 - 7 } Parameters & 100.00 & 90.10 & 80.20 & 70.30 & 60.40 & 50.50 \\
\hline Thickness $(\mathrm{cm})$ & $3.68^{\mathrm{b}} \pm 0.04$ & $4.05^{\mathrm{a}} \pm 0.02$ & $4.06^{\mathrm{a}} \pm 0.11$ & $3.98^{\mathrm{a}} \pm 0.06$ & $4.07^{\mathrm{a}} \pm 0.03$ & $4.09^{\mathrm{a}} \pm 0.05$ \\
\hline Diameter $(\mathrm{cm})$ & $4.31^{\mathrm{b}} \pm 0.10$ & $4.29^{\mathrm{a}} \pm 0.05$ & $4.21^{\mathrm{a}} \pm 0.03$ & $4.19^{\mathrm{a}} \pm 0.02$ & $4.20^{\mathrm{a}} \pm 0.05$ & $4.16^{\mathrm{a}} \pm 0.08$ \\
\hline Spread ratio & $1.17^{\mathrm{a}} \pm 0.06$ & $1.06^{\mathrm{b}} \pm 0.02$ & $1.04^{\mathrm{b}} \pm 0.04$ & $1.05^{\mathrm{b}} \pm 0.08$ & $1.03^{\mathrm{b}} \pm 0.02$ & $1.02^{\mathrm{b}} \pm 0.04$ \\
\hline
\end{tabular}

Each value is the mean of triplicate determinations. Means on the same column with different superscripts are significantly different at $\mathrm{P}=0.05$.

These variations in the biscuit thickness and diameter were reflected in the spread ratio of the biscuits which was calculated by dividing the diameter by the thickness. The spread ratio is an important characteristic for determining the quality of flour for biscuit production. Biscuits with higher spread ratio values are considered to be more desirable than those with lower values [58, 59]. The spread ratio of the biscuits varied from 1.02 to 1.17 with the unfortified biscuit (control) having the highest value while the $50 \%$ cowpea flour substituted biscuit had the least value. Similar reduction in spread ratio of biscuits as a result of incorporation of pea, pigeon pea, pea and soy flours were reported by Kamaljit et al. [60], Tiwari et al. [56], 
Kohajdová et al. [57] and Man et al. [1] respectively. Spread ratio is influenced by water retention of flours and dough viscosity as dough with lower viscosity causes biscuit to spread faster. According to Zucco et al. [59], for blends containing legume flours, the increasing number of hydrophilic sites available due to increased protein content competes for the limited free water in the dough during mixing with resultant increased in dough viscosity, thereby limiting the spread ratio.

\section{Effect of the Treatment on the Nutrient Content in the Prepared Biscuits}

The nutrients composition of biscuits prepared from acha - green banana composite flour supplemented with cowpea flour is presented on Table 3.

Table-3: Nutrient composition of biscuit made from composite of acha-green banana flours fortified with cowpea flour (dry matter basis)

\begin{tabular}{|l|c|c|c|c|c|c|}
\hline \multirow{2}{*}{ Parameters } & \multicolumn{6}{|c|}{ Blending ratios (acha-banana flour: cowpea flour) } \\
\cline { 2 - 7 } & 100.00 & 90.10 & 80.20 & 70.30 & 60.40 & 50.50 \\
\hline Protein (\%) & $9.57^{\mathrm{f}} \pm 0.05$ & $11.71^{\mathrm{e}} \pm 0.02$ & $12.79^{\mathrm{d}} \pm 0.10$ & $14.13^{\mathrm{c}} \pm 0.06$ & $16.05^{\mathrm{b}} \pm 0.03$ & $17.41^{\mathrm{a}} \pm 0.06$ \\
\hline Fat $(\%)$ & $10.86^{\mathrm{a}} \pm 0.11$ & $11.12^{\mathrm{a}} \pm 0.06$ & $11.40^{\mathrm{a}} \pm 0.08$ & $11.63^{\mathrm{a}} \pm 0.03$ & $11.81^{\mathrm{a}} \pm 0.05$ & $12.01^{\mathrm{a}} \pm 0.02$ \\
\hline Ash (\%) & $2.48^{\mathrm{a}} \pm 0.08$ & $2.40^{\mathrm{a}} \pm 0.03$ & $2.34^{\mathrm{a}} \pm 0.05$ & $2.25^{\mathrm{a}} \pm 0.10$ & $2.18^{\mathrm{a}} \pm 0.02$ & $2.13^{\mathrm{a}} \pm 0.11$ \\
\hline Crude Fibre (\%) & $1.92^{\mathrm{b}} \pm 0.04$ & $2.01^{\mathrm{b}} \pm 0.05$ & $2.12^{\mathrm{b}} \pm 0.02$ & $2.20^{\mathrm{a}} \pm 0.08$ & $2.29^{\mathrm{a}} \pm 0.02$ & $2.41^{\mathrm{a}} \pm 0.05$ \\
\hline Carbohydrate $(\%)$ & $75.17^{\mathrm{a}} \pm 0.10$ & $72.76^{\mathrm{b}} \pm 0.04$ & $71.35^{\mathrm{b}} \pm 0.06$ & $69.79^{\mathrm{c}} \pm 0.02$ & $67.67^{\mathrm{c}} \pm 0.04$ & $66.04^{\mathrm{d}} \pm 0.03$ \\
\hline $\begin{array}{l}\text { Caloric Value } \\
\text { (kcal/100g) }\end{array}$ & $436.70^{\mathrm{b}} \pm 0.03$ & $437.96^{\mathrm{b}} \pm 0.08$ & $439.16^{\mathrm{a}} \pm 0.03$ & $440.35^{\mathrm{a}} \pm 0.05$ & $441.17^{\mathrm{a}} \pm 0.06$ & $441.89^{\mathrm{a}} \pm 0.04$ \\
\hline Ca (mg/100g) & $31.79^{\mathrm{f}} \pm 0.21$ & $33.91^{\mathrm{e}} \pm 0.15$ & $35.86^{\mathrm{d}} \pm 0.09$ & $37.78^{\mathrm{c}} \pm 0.10$ & $40.00^{\mathrm{b}} \pm 0.13$ & $43.95^{\mathrm{a}} \pm 0.16$ \\
\hline $\mathrm{K}(\mathrm{mg} / 100 \mathrm{~g})$ & $78.84^{\mathrm{a}} \pm 0.09$ & $74.46^{\mathrm{b}} \pm 0.20$ & $69.52^{\mathrm{c}} \pm 0.12$ & $65.61^{\mathrm{d}} \pm 0.18$ & $60.83^{\mathrm{c}} \pm 0.08$ & $56.90^{\mathrm{f}} \pm 0.11$ \\
\hline Fe (mg/100g) & $3.01^{\mathrm{f}} \pm 0.13$ & $3.28^{\mathrm{e}} \pm 0.08$ & $3.61^{\mathrm{d}} \pm 0.14$ & $3.97^{\mathrm{c}} \pm 0.05$ & $4.14^{\mathrm{b}} \pm 0.11$ & $4.58^{\mathrm{a}} \pm 0.20$ \\
\hline $\mathrm{Zn}(\mathrm{mg} / 100 \mathrm{~g})$ & $1.95^{\mathrm{f}} \pm 0.11$ & $2.17^{\mathrm{a}} \pm 0.16$ & $2.45^{\mathrm{d}} \pm 0.06$ & $2.71^{\mathrm{c}} \pm 0.12$ & $2.95^{\mathrm{b}} \pm 0.15$ & $3.23^{\mathrm{a}} \pm 0.14$ \\
\hline
\end{tabular}

Each value is the mean of triplicate determinations. Means on the same column with different superscripts are significantly different at $\mathrm{P}=0.05$.

The result showed that the crude protein, fat, crude fibre, calcium, iron and zinc contents in the biscuits progressively increased while the ash, carbohydrate and potassium contents progressively decreased with increase in cowpea flour substitution. The crude protein significantly $(\mathrm{p}<0.05)$ increased from $9.57 \%$ in the biscuit prepared from unfortified flour (control) to $17.41 \%$ in the $50 \%$ cowpea flour substituted biscuit while the carbohydrate content significantly $(p<0.05)$ decreased from $75.17 \%$ in the biscuit made from the unfortified flour to $66.04 \%$ in the $50 \%$ cowpea flour substituted biscuit. The increased in protein content and decreased in carbohydrate content with increasing level of cowpea flour substitution could be attributed to higher protein content and lower carbohydrate content in cowpea flour than in achabanana composite flour. Other researchers [1, 43, 61, 62] have made similar reports for legume flour fortified products. Foods rich in protein content are of great nutritional important in developing country such as Nigeria where protein - energy malnutrition is still prevalent in rural communities. Batool et al. [63] stated that fortification of carbohydrate - based foods with legumes is significant in places where many people can hardly afford high protein foods because of their high cost. The high protein content in cowpea flour fortified biscuits therefore suggests that upon consumption, they would help to alleviate protein - energy malnutrition among the vulnerable groups with limited access to animal proteins.
The fat content in the biscuits insignificantly ( $p>0.05$ ) increased from $10.86 \%$ in the control sample to $12.01 \%$ in the $50 \%$ cowpea flour fortified biscuit. The least fat content in the biscuit prepared from unfortified flour is not surprising as both acha and green banana have very low fat content. The slight increase in fat content in the biscuits with increase in cowpea flour substitution may be attributed to lower fat content in acha - green banana composite flour than in cowpea flour. The fat contents obtained in the present study were slightly lower than the range $(12.00-13.50 \%)$ reported by Inyang et al. [62] for gluten free biscuit produced from unripe banana and sweet potato composite flour supplemented with red kidney been flour. Fat is a rich source of energy; serves as a lubricating agent that improves the mouth feel, flavor and palatability of foods and also serves as carrier of fat soluble vitamins A, D, E and K [64].

The ash content of a food sample is an index of the mineral elements of such food. The ash content in the prepared biscuit insignificantly $(p>0.05)$ decreased with increase in cowpea flour substitution ranging from $2.48 \%$ for the biscuit made from unfortified flour to $2.13 \%$ for the $50 \%$ cowpea flour substituted biscuit. The ash content values obtained in the present study were close to the range of $1.74-2.39 \%$ reported by Adeola and Ahizua [65] for biscuit made from blends of unripe cooking banana, pigeon pea and sweet potato flours. 
The crude fibre content of the biscuit increased progressively from $1.92 \%$ for the biscuit prepared from unfortified flour to $2.41 \%$ for the $50 \%$ cowpea flour fortified biscuits. The increase could be due to higher crude fibre content in cowpea flour than in acha - green banana composite flour. The crude fibre values were within the range $(0.98-3.51 \%)$ reported by Adeola and Ohizua [65] for biscuits from blends of unripe cooking banana, pigeon pea and sweet potato flours. Similar increases in crude fibre content in biscuits fortified with legume flours have been reported $[62,66]$. Dietary fibre has been shown to have a great impact on the health of consumers. Consumption of high dietary fibre food products has been linked to the reduction of mortality and morbidity from several chronic diseases, such as cardiovascular disease (CVD), type-2 diabetes, colorectal cancer, obesity, high blood pressure and also lowers serum cholesterol [67]. Dietary fibre also facilitates regularity and alleviates constipation. The caloric value of the biscuits increased from $436.70 \mathrm{kcal} / 100 \mathrm{~g}$ for the control sample to $441.98 \mathrm{kcal} / 100 \mathrm{~g}$ for $50 \%$ cowpea flour substituted biscuit. The protein, fat and carbohydrate constituents contributed to the calculated caloric value of the biscuits with fat as the major contributor $(9 \mathrm{kcal} / \mathrm{g})$ while protein and carbohydrate contributed $4 \mathrm{kcal} / \mathrm{g}$. This explains why the control sample with the least fat content recorded the least caloric value and $50 \%$ cowpea flour substituted biscuit with the highest fat value also had the highest caloric value.

Mineral nutrients are very significant and vital constituents of diet needed for a wide variety of essential and metabolic and/or structural functions in the body. They help the body to grow, develop and stay healthy. Inadequate intakes of minerals have been associated with severe malnutrition, increased disease conditions and mental impairment [68]. The contents of mineral nutrients $(\mathrm{Ca}, \mathrm{K}, \mathrm{Fe}$ and $\mathrm{Zn})$ in the biscuit samples are shown in Table 4 . The calcium content in the biscuits increased with increase in cowpea flour substitution ranging from $31.79 \mathrm{mg} / 100 \mathrm{~g}$ in the unfortified biscuit to $43.95 \mathrm{mg} / 100 \mathrm{~g}$ in the $50 \%$ cowpea flour substituted biscuit. The increased in calcium content with increase in cowpea flour substitution could be attributed to higher calcium content in cowpea flour than in acha-banana composite flour. Singh et al. [69] and Pereira et al. [70] reported that calcium is one of the major minerals in cowpea grains. Tharanathan and Mahadeyamma [16] reported that cowpea has more calcium than meat. Calcium is important for developing and maintaining bones and teeth and for supporting the healthy functioning of muscles, nerves and heart [71, 72]. Adequate dietary intake of calcium is required throughout life to prevent low bone mineral density, risk of bone fragility and osteoporosis at a mature age [72].

The potassium content in the biscuits significantly $(\mathrm{p}<0.05)$ decreased with increase in cowpea flour substitution ranging from $78.84 \mathrm{mg} / 100 \mathrm{~g}$ in the biscuit prepared from the unfortified flour to $56.90 \mathrm{mg} / 100 \mathrm{~g}$ in the $50 \%$ cowpea flour substituted biscuit. Potassium is the dominant mineral element present in banana pulp and peel [73] and in acha grains $[74,75]$. The decreased in potassium values with increase in cowpea flour substitution could therefore be due to higher content of potassium in acha - green banana composite flour than in cowpea flour. Potassium is the principal cation in intracellular fluid and functions in acid-base balance regulation of osmotic pressure, conduction of nerve impulse, muscle contraction particularly the cardiac muscle, cell membrane function and $\mathrm{Na}^{+} / \mathrm{K}^{+}-$ATPase [71].

Iron and zinc are minerals that regulate important processes in the bodies of healthy individuals. Deficiencies of micronutrients like $\mathrm{Fe}$ and $\mathrm{Zn}$, recognized as hidden hunger, are the most prevalent health disorders worldwide, affecting nearly two billion people [76]. The iron and zinc contents in the biscuit samples increased significantly $(\mathrm{p}<0.05)$ with increase in the percentage of cowpea flour substitution ranging from $3.01 \mathrm{mg} / 100 \mathrm{~g}$ and $1.95 \mathrm{mg} / 100 \mathrm{~g}$ in the biscuit prepared from the unfortified flour to $4.58 \mathrm{mg} / 100 \mathrm{~g}$ and $3.23 \mathrm{mg} / 100 \mathrm{~g}$ respectively in the $50 \%$ cowpea flour substituted biscuit. The recorded increase in iron and zinc contents in the biscuits with increase in cowpea flour substitution could be attributed to their higher contents in cowpea flour than in acha - banana composite flour. Pereira et al. [70] reported that cowpea is an excellent source of iron and zinc and can be used for the low income population who suffer from a deficiency of these micronutrients. Tharanathan and Mahadeyamma [16] reported that iron content in cowpea is equal to the value in milk. Iron is essential in human diet for the respiration process, the transport of oxygen in the blood and in the oxygenation of red blood cells [71]. Iron deficiency often leads to anemia, tissue inflammation and fatigue [71]. Moreira-Araújo and Brandāo [77] reported that cowpea flour is a new material with great potential to be used in the development of products aimed at children as a strategy to reduce and/or control iron deficiency anemia. Zinc is essential for the synthesis of DNA and RNA, protein, insulin, and for proper functioning of immunity system and for activation of over 80 enzymes [72]. Its deficiency can affect normal growth and development of children, physical senses such as smell and taste and can also result in anorexia and skin disease [78].

\section{Effect of the Treatment on Sensory Characteristics of the Prepare Biscuits}

Sensory evaluation of food is an integral part of new food product development or product improvement as it is used to evaluate product acceptance or rejection by the potential consumers. Mean sensory scores for biscuit characteristics evaluated (colour, taste, aroma, texture, crispness and overall acceptability) are presented on Table 4. 
Table-4: Mean sensory value of biscuit produced from composite of acha-green banana flours fortified with cowpea flour

\begin{tabular}{|l|c|c|c|c|c|c|}
\hline \multirow{2}{*}{ Sensory Attributes } & \multicolumn{5}{|c|}{ Blending ratios (acha-banana flour: cowpea flour) } \\
\cline { 2 - 7 } & 100.00 & 90.10 & 80.20 & 70.30 & 60.40 & 50.50 \\
\hline Colour & $6.43^{\mathrm{b}} \pm 0.20$ & $6.75^{\mathrm{b}} \pm 0.14$ & $7.18^{\mathrm{a}} \pm 0.10$ & $7.10^{\mathrm{a}} \pm 0.31$ & $7.21^{\mathrm{a}} \pm 0.22$ & $7.24^{\mathrm{a}} \pm 0.15$ \\
\hline Taste & $6.89^{\mathrm{b}} \pm 0.14$ & $6.97^{\mathrm{a}} \pm 0.09$ & $7.02^{\mathrm{a}} \pm 0.21$ & $6.35^{\mathrm{c}} \pm 0.15$ & $6.10^{\mathrm{d}} \pm 0.16$ & $5.63^{\mathrm{e}} \pm 0.20$ \\
\hline Aroma & $6.81^{\mathrm{a}} \pm 0.31$ & $6.88^{\mathrm{a}} \pm 0.20$ & $6.93^{\mathrm{a}} \pm 0.13$ & $6.59^{\mathrm{c}} \pm 0.19$ & $5.86^{\mathrm{d}} \pm 0.30$ & $5.47^{\mathrm{e}} \pm 0.11$ \\
\hline Texture & $6.04^{\mathrm{c}} \pm 0.19$ & $7.20^{\mathrm{a}} \pm 0.11$ & $7.31^{\mathrm{a}} \pm 0.14$ & $6.74^{\mathrm{b}} \pm 0.08$ & $6.03^{\mathrm{c}} \pm 0.10$ & $5.70^{\mathrm{d}} \pm 0.14$ \\
\hline Crispness & $6.73^{\mathrm{b}} \pm 0.10$ & $6.61^{\mathrm{b}} \pm 0.13$ & $6.96^{\mathrm{a}} \pm 0.10$ & $6.98^{\mathrm{a}} \pm 0.15$ & $6.27^{\mathrm{c}} \pm 0.21$ & $6.15^{\mathrm{d}} \pm 0.09$ \\
\hline Overall Acceptability & $6.82^{\mathrm{c}} \pm 0.15$ & $7.13^{\mathrm{b}} \pm 0.21$ & $7.65^{\mathrm{a}} \pm 0.09$ & $6.26^{\mathrm{d}} \pm 0.11$ & $5.96^{\mathrm{e}} \pm 0.14$ & $5.37^{\mathrm{f}} \pm 0.20$ \\
\hline
\end{tabular}

Means on the same column with different superscripts are significantly different at $\mathrm{P}=0.05$.

The result showed that the mean scores by the panellists for each of the sensory attributes varied among the biscuit samples. Colour is an important sensory attribute that induces the first response for the product by the consumers. Fortification of acha- green banana composite flour with cowpea flour led to the improvement of the biscuit colour as the mean score for the unfortified biscuit was lower than the scores for the cowpea fortified biscuits. The mean scores for the colour of the prepared biscuits ranged from 6.43 for the biscuit made from unfortified flour to 7.24 for $50 \%$ cowpea flour fortified biscuit. There was no significant $(\mathrm{P}>0.05)$ difference between the colour of unfortified biscuit and 10\% cowpea flour substituted biscuit but their mean scores were significantly $(\mathrm{P}<0.05)$ lower than the mean score values for biscuits fortified with 20 - $50 \%$ cowpea flour.

Flavour (taste and aroma) of a food is a sensory attribute that ultimately determines its acceptance or rejection by the consumers. The mean scores for taste and aroma of the biscuits ranged from 5.63 and 5.47 for the $50 \%$ cowpea flour substituted biscuit to 7.02 and 6.93 respectively for $20 \%$ cowpea flour substituted biscuit. Mean scores for the taste of $10 \%$ and $20 \%$ cowpea flour substituted biscuits were not significantly $(\mathrm{P}>0.05)$ different from each other but they were significantly $(\mathrm{p}<0.05)$ higher than the scores for the other samples. The mean scores for aroma of unfortified biscuit and cowpea flour fortified biscuits up to $20 \%$ substitution level did not differ from each other but were significantly $(\mathrm{P}<0.05)$ higher than the scores for samples with more than $20 \%$ cowpea flour substitution. Mean sensory scores for taste and aroma of biscuit samples containing more than $20 \%$ cowpea flour substitution decreased significantly $(\mathrm{p}<0.05)$ with increase in cowpea flour substitution.

Texture of the prepared biscuits determined their chewing ability and therefore played an important role in justifying their overall acceptability. The mean score values for the texture ranged from 5.70 to 7.31 with the $50 \%$ cowpea flour substituted biscuit having the lowest score while the $20 \%$ cowpea flour substituted biscuit had the highest score. The mean scores for crispness of the biscuits ranged from 6.15 for the $50 \%$ cowpea flour substituted biscuit to 6.98 for the $30 \%$ cowpea flour substituted biscuit. For the overall acceptability of the biscuits, the mean scores by the panellists ranged from 5.37 for the $50 \%$ cowpea flour substituted biscuit to 7.65 for the $20 \%$ cowpea flour substituted biscuit. Overall acceptability scores for biscuit samples containing more than $20 \%$ cowpea flour decreased significantly $(\mathrm{P}<0.05)$ with increase in cowpea flour substitution. It is evident from the mean score values for overall acceptability that the most acceptable biscuit was prepared from the blend of $80 \%$ acha-green banana composite flour and $20 \%$ cowpea flour.

\section{Conclusion}

The study has shown that fortification of achagreen banana composite flour with cowpea flour affected the pasting behaviour of the flour blends as well as the nutrient composition, physical and sensory attributes of biscuits made from the blends. Except for the pasting time and pasting temperature that increased with cowpea flour substitution, the other pasting properties of the flour blends were reduced. The increased in protein, iron and zinc contents in the prepared biscuits as a result of cowpea flour inclusion is of great significant as consumption of the biscuits could help to alleviate the problem of protein - energy malnutrition and deficiency of these micronutrients that are of public health concern worldwide. Also, the higher dietary fibre content in cowpea flour fortified biscuits than in the unfortified biscuits would provide some health benefits to the consumers. Based on the sensory evaluation result, the blend of $80 \%$ acha-green banana composite flour and $20 \%$ cowpea flour to produce acceptable gluten - free biscuit of high nutritional value is recommended. The use of composite flour from these locally grown crops for biscuit production will reduce the demand for imported wheat grains, increase the utilization of these crops and their economic value and add variety to the biscuit grocery store for the consumers, especially celiac patients.

\section{REFERENCES}

1. Man, S., Paucean, A., \& Muste, S. (2014). Preparation and quality of gluten-free biscuit. Bulletin of University of Agriculture and Veterinary Medicine (UASVM), Cluj-Napoca Food Science and Technology, 7(1):39-41. 
2. Klunklin, W., \& Savage, G. (2018). Biscuit: A substitution of wheat flour with purple rice flour. Advances in Food Science and Engineering, 2(3):81-97.

3. Pelkowski, T. D., \& Viera, A. J. (2014). Celiac disease: Diagnosis and management. American Family Physician, 89(2):99-105.

4. Kamram, M., Saleem, N., \& Umer, Z. N. (2008). Ready-to-eat (RTE) wheat bran breakfast cereal as a high fibre diet. Journal of Food Processing and Preservation, 32:853-867.

5. Švec, I., \& Hrušková, M. (2018). Baking value of wheat-fonio flour composites. Advances in Food Science and Engineering, 2(2):59-69.

6. Ayo, J. A., Ibrahim, A., \& Nkama, I. (2003). Effect of acha (D. exilis) on the body weight, blood glucose level, hemoglobin and packed column cell of rabit. Book of Proceedings, National Conference on the Application of Science for National Development, Mubi, Adamawa State, Nigeria, 25$28,56$.

7. de Lumen, B. O., Thompson, S., \& Odegard, J. W. (1993). Sulphur amino-rich proteins in acha (Digitaris exilis), a promising underutilized African cereal. Journal of Agriculture and Food Chemistry, 41:1045-1047.

8. Jideani, I. A., \& Jideani, V. A. (2011). Development on the cereal grains Digitaria exilis (acha) and Digitaria Iburua (Iburu). Journal of Food Science and Technology, 48(3):215-259.

9. Aurore, G., Parfait, B., \& Fahrasane, L. (2009). Banana, raw materials for making processed food products. Trends in Food Science and Technology, 20:78:91.

10. Cheok, C. Y., Sulaiman, R., Manan, N. A., Zakora, A. J., Chin, N. L., \& Hussain, N. (2018). Pasting and physical properties of green banana flours and pastas. International Food Research Journal, 25(6):2585-2592.

11. Borges, C. V., De Oliveira Amorin, V. B., Ramlov, F., Da Silva Ledo, C. A., Donata, M., Maraschino, M. and Amorin, E. P. (2014). Characterization of metabolic profile of banana genotype, aiming at biofortified Musa spp cultivars. Food Chemistry, 145:496-504.

12. Hermández-Aguirre, M. A., Islas-Hermández, J. J., Sánchez-Pardo, M. E., Rodriguez-Ambriz, S. L., \& Osorio-Diaz, P. (2019). Response surface methodology for optimization of gluten-free bread made with unripe banana flour. Journal of Food Measure and Characterization, 13:165-1600.

13. Bodinham, C. L., Frost, C. L., \& Robertson, M. D. (2009). Acute ingestion of resistant starch reduces food intake in healthy adults. British Journal of Nutrition, 27:1-6.

14. Scarminio, V., Fruet, A. C., Witaicenis, A., Rall, V. L. M., \& Di Stasi, L. C. (2012). Dietary intervention with green dwarf banana flour (Musa sp. $A A A)$ prevents intestinal inflammation in a trinitrobenzene sulfonic acid model of rat colitis. Nutrition Research, 32:202-209.

15. Appiah, F., Asibuo, J., \& Kumah, P. (2011). Physicochemical and functional properties of bean flours of three cowpea (Vigna unguiculata Walp) varieties in Ghana. African Journal of Food Science, 5(2):100-104.

16. Tharanathan, R. N., \& Mahadevamma, S. (2003). Grain legumes - a boon to human nutrition. Trends in Food Science and Technology, 14(12):507-518.

17. Adediran, A. M., Ramota, K. O., Adeoye, O. S., Toyin, O. A., \& Awonorin S. O. (2013). Physicochemical properties and akara making potentials of pre-processed jack beans (Canavalia ensiformis) and cowpea (Vigna unguiculata $L$. Walp) composite flour. Croatian Journal of Food Technology, Biotechnology and Nutrition, 8(3-4): 102-110.

18. Ayo, J. A. A., \& Okeye, E. (2020). Nutrient composition and functional properties of fonio (Digitaria exilis) and amaranthus (Amaranthus cruentus) flour blends. Asian Food Science Journal, 16(3):53-62.

19. Anggraeni, R., \& Saputra, D. (2018). Physicochemical characteristics and sensorial properties of dry noodle supplemented with unripe banana flour. Food Research, 2(3):270-278.

20. Akosua, A. J. Kwasi, K. F. M., Sedem, D. C., \& Christopher, M. (2015). Development and assessment of conformance of cowpea flour for cake production. International Journal of Nutrition and Food Sciences, 4(3):320-325.

21. Poopola, O. O., Balogun, D. A., Bello, A., Adeyemi, H. J., Jibrin, J., Isijiola, B., Hassan, N. M., Kumapayi, T. A., Odeh, E., Raji, M. O., Ajibola, O. T. and Ajulo, K. (2019). Quality characteristics of biscuit baked from acha-ripe plantain. Research Journal of Food Science and Quality Control, 5(1):12-20.

22. Newport Scientific. (1998). Application manual for the Rapid Visco Analyzer using thermocline for windows, Newport Scientific Pty Ltd, Australia, pp. 2-26.

23. Kaur, M., \& Singh, N. (2005). Studies on functional, thermal and pasting properties of flours from different chickpea (Cicer arietinum L.) cultivars. Food Chemistry, 91:403-411.

24. AOAC. (2005). Official Methods of Analysis (18 edn.). Association of Official Analytical Chemists, Washington DC, USA.

25. Onwuka, G. I. (2005). Food analysis and instrumentation. Naphthali Prints, Lagos, Nigeria, 89.

26. Osborne, D. R., \& Voogt, P. (1978). The analysis of nutrients in foods. Academic press, New York, 237.

27. Iwe, M. O. (2007). Current trends in sensory evaluation of foods. Rojoint Communication Services Ltd, Enugu, Nigeria, 137-138. 
28. Ragaee, S., \& Abdel-Aal, E. S. M. (2006). Pasting properties of starch and protein in selected cereals and quality of their food products. Food Chemistry, 95(1):9-18.

29. Adebowale, A. A., Sanni, L. O., \& Awonorin, S. O. (2005). Effect of texture modifies on the physicochemical and sensory properties of dried fufu. Food Science International Journal, 11:373382.

30. Onweluzo, J. C., \& Nnamuchi, O. M. (2009). Production and evaluation of porridge-type breakfast product from Treculia Africana and Sorghum Bicolor flours. Pakistan Journal of Nutrition, 8:731-736.

31. Ajanaku, K. O., Ajanaku, C. O., Edobbor-Osoh, A. and Nwinyi, O. C. (2012). Nutritive value of sorghum ogi fortified with groundnut seed (Arachis hypogaea L.). American Journal of Food Technology, 7:82-88.

32. Morris, V. J. (1990). Starch gelation and retrogradation. Trends in Food Science and Technology, 1:2-6.

33. Adebowale, A. A., Sanni, L. O., \& Ladapo, F. O. (2008). Chemical, functional and sensory properties of instant yam-breadfruit flour. Nigerian Food Journal, 26(1):1173-1178.

34. Otunola, G. A., \& Afolayan, A. J. (2018). Evaluation of the physicochemical, proximate, and sensory properties of moin moin from blends of cowpea and water yam. Food Science and Nutrition, 6(4):991-997.

35. Maziya-Dixon, B., Dixon, A. G., \& Adebowale, A. A. (2007). Targeting different uses of cassava geotropic variation for cyanogenic potential and pasting properties. International Food Science and Technology, 42:969-976.

36. Tan, Y., \& Corke, A. (2002). Factor analysis of physicochemical properties of 63 rice varieties. Journal of the Science of Food and Agriculture, 82:745-752.

37. Shittu, T. A., Lasekan, O. O., Sanni, L. O., \& Oladosu, M. O. (2001). The effect of drying methods on the functional and sensory characteristics of pupuru - a fermented cassava product. The Asset Journal, 1(2):9-16.

38. Tharise, N., Julianti, E., \& Nurminah, M. (2014). Evaluation of physicochemical and functional properties of composite flour from cassava, rice, potato, soybean and xanthan gum as alternative of wheat flour. International Food Research Journal, 21(4):1614-1649.

39. Ouazib, M., Dura, A., Zaidi, F., \& Rosell, C. M. (2016). Effect of partial substitution of wheat flour by processed (germinated, roasted, cooked) chickpea on bread quality. International Journal of Agricultural Science and Technology, 4(1):8-18.

40. Ohizua, E. R., Adeola, A. A., Idowu, M. A., Sobukola, O. P., Afolabi, T. A., Ishola, R. O., Ayansina, S. O., Oyekale, T. O., \& Falomo, A. (2017). Nutrient composition, functional, and pasting properties of unripe cooking banana, pigeon pea, and sweet potato flour blends. Food Science and Nutrition, 5(3):750-762.

41. Abioye V. F., Ade-Omowaye, B.I.O., Babarinde, G. O., \& Adesigbin, M. K. (2011). Chemical, physicochemical and sensory properties of soyplantain flour. African Journal of Food Science, 5(4): 178-180.

42. Ayo-Omogie, H. N., \& Ogunsakin, R. (2013). Assessment of chemical, rheological and sensory properties of fermented maize - cardaba banana complementary food. Food and Nutrition Science, 4:844-850.

43. Olapade, A. A., \& Adeyemo, A. M. (2014). Evaluation of cookies produced from blends of wheat, cassava and cowpea flour. International Journal of Food Science, 3:175-185.

44. Badejo, A. A., Osunlakin, A. P., Famakinwa, A., Idowu, A. O., \& Fagbemi, T. N. (2017). Analysis of dietary fibre contents of plantain and moringa composite flour blends. Cogent Food and Agriculture, $3(1)$ :dio.org/ 10.1080/23311932.2017.1278871.

45. Julianti, E., Rusmarilin, H., Ridwansyah, R., Yusraini, E. (2017). Functional and rheological properties of composite flour from sweet potato, maize, soybean and xanthan gum. Journal of the Saudi Society of Agricultural Sciences, 16(2):171177.

46. Bakare, A. A., Osundahunsi, O. F., \& Olusanya, J. O. (2015). Rheological, baking and sensory properties of composite blend dough with breadfruit (Artocarpus communis Forst) and wheat flours. Food Science and Nutrition, DOI:10.1002/fsn3.321.

47. Ajatta, M.A., Akinola, S.A., \& Osundahunsi, O.F. (2016). Proximate, functional and pasting properties of composite flours made from wheat, breadfruit and cassava starch. Applied Tropical Agriculture, 21 (3): 158-165.

48. Tester, R. F., \& Morrison, W. R. (1990). Swelling and amylosization of cereal starches. I. Effect of amylopectin, amylose and lipid. Cereal Chemistry, 67:551-557.

49. Ratnawati, L., Desnilasari, D., Kumalasari, R. and Surahman, D. N. (2020). Characterization of modified cassava flour (mocaf) - based biscuit substituted with soybean flour at varying concentrations and particle sizes. Food Research, 4(3):635-651.

50. Shahzad, S. A., Hussain, S., Mohamed, A. M., Alamri, M. S., Ibraheem, M. A. and Qasen, A. A. A. (2019). Effect of hydrocolloid gums on the pasting, thermal, rheological and textural properties of chickpea starch. Foods, 8(12):687, doi: 10.3390/foods8120687.

51. Akanbi, C. T., \& Ikujenlola, A. V. (2016). Physicochemical composition and glycemic index of whole grain bread produced from composite flours of quality protein maize and wheat. Croatian 
Journal of Food Science and Technology, 8(1); doi:10.17508/CJFST.2016.8.1.01.

52. Peroni, F. H. G., Rocha, T. S., \& Franco, C. M. L. (2006). Some structural and physicochemical characteristics of tuber and root starches. Food Science and Technology International, 12:505-510.

53. Otegbayo, B. O., Aina, J. O., Asiedu, R., \& Bokanga, M. (2006). Pasting characteristics of fresh yams (Dioscorea spp) as indicators of textural quality in major food product "pounded yam". Food Chemistry, 99:663-669.

54. Choi, I., Kang, C., Cheong, Y., Hyun, T., \& Kim, K. (2012). Substituting normal and waxy-type whole wheat flour on dough and baking. Preventive Nutrition and Food Science, 17(3):197-202.

55. Zeng, F., Liu, H., \& Liu, G. (2013). Physicochemical properties of starch extracted from Colocasia esculenta (L) Schott (Bun-Long taro) grown in Hunan, China. Starch/stärke, 65:1-7.

56. Tiwari, B. K., Brennan, C. S., Jaganmohan, R., Surabi, A., \& Alagusundaram, K. (2013). Utilization of pigeon pea (Cajanus cajan L.) byproduct in biscuit manufacture. LWT - Food Science and Technology, 44(6):1533-1537.

57. Kohajdová, Z., Karovicova, J., \& Magala, M. (2013). Rheological and qualitative characteristics of pea flour incorporated cracker biscuits. Croatian Journal of Food Science and Technology, 5(1):1117.

58. Hussein, A. M. S., Amal, S. A., Amany, M. H., Abeer, A. A., \& Gamal, H. R. (2011). Physicochemical, sensory and nutritional properties of corn-fenugreek flour composite biscuits. Australian Journal of Basic and Applied Sciences, 57:84-95.

59. Zucco, F., Borsuk, Y., \& Arnfield, S. D. (2011). Physical and nutritional evaluation of wheat cookies supplemented with pulse flour of different particle sizes. LWT-Food Science and Technology, 44(10):2070-2076.

60. Kamaljit, K., Baljeet, S., \& Amarjeet, K. (2010). Preparation of bakery products by incorporating pea flour as functional ingredients. American Journal of Food Technology, 5(2):130-135.

61. Igbabul, B. D., Iorliam, B. M., \& Umana, E. N. (2015). Physicochemical and sensory properties of cookies produced from composite of wheat, cocoyam and African yam bean. Journal of Food Research, 4(2):150-158.

62. Inyang, U. E., Udofia, C. B., \& Ukwo, S. P. (2017). Functional properties and quality characteristics of gluten free biscuits made from unripe banana and sweet potato composite flour supplemented with red kidney bean flour. Journal of Advances of Food Science and Technology, 4(3):100-108.

63. Batool, R., Butt, M. S., Sultan, M. T., Saeed, F., \& Naz, R. (2015). Protein-energy malnutrition: A risk factor for various ailments. Critical Review in Food Science and Nutrition, 55(2):242-253.
64. Ikuomola, D. S., Otutu, O. L., \& Oluniran, D. D. (2017). Quality assessment of cookies produced from wheat flour and malted barley (Hordeum vulgare) bran blend. Cogent Food and Agriculture, https://doi.org/10.1080/ 23311932.2017.1293471.

65. Adeola, A. A., \& Ohizua, E. R. (2018). Physical, chemical and sensory properties of biscuits prepared from blends of unripe cooking banana, pigeon pea and sweet potato. Food Science and Nutrition, 6(3):532-540.

66. Awan, J. A., Rehinan, A., Rehinan, S., Siddique, M. I. and Hashmi, A. S. (1995). Evaluation of biscuits prepared from composite flour containing mothbean flour. Paskistan Journal of Agricultural Science, 32(1):211-217.

67. Academy of Nutrition and Dietetics. (2015). Position of the Academy of Nutrition and Dietetics: Health Implications of Dietary Fibre. Journal of the Academy of Nutrition and Dietetics, 115:18611870.

68. Abulude, F. O. (2005). Distribution of selected minerals in some Nigerian white bread. Nigerian Food Journal, 23: 139-147.

69. Singh, R. J., Chung, G. H. and Nelson, R. L. (2007). Landmark research in legumes. Genome, 50:525-537.

70. Pereira, E. J., Cardosco, L. M., Dellamora-Ortiz, G. M., Cardosco, F. S., Carvalho, J. L., Viana, D. S., Freitas, S. C. and Rocha, M. M. (2014). Effect of cooking method on the iron and zinc contents in cowpea (Vigna unguiculata) to combat nutritional deficiencies in Brazil. Food and Nutrition Research, 58:20694, http://dx.doi.org/10.3402/fnr.v58.20694.

71. Soetan, K. O., Olaiya, C. O., \& Oyewole, O. E. (2010). The importance of mineral elements for humans, domestic animals and plants: A review. African Journal of Food Science, 4(5):200-222.

72. Lilly, T. T., Immculata, J. K., \& Jamila, P. (2017). Macro and micronutrients of selected marine fishes in Tuticorin, South East Coast of India. International Food Research Journal, 24(1):191201.

73. Sulaiman, S. F., Yusoff, N. A. M., Eldeen, I. M., Seow, E. M., Sajak, A.A. B., \& Supriatno, K. L. O. (2011). Correlation between total phenolic and mineral contents with antioxidant acivity of eight Malaysian banana (Musa spp). Journal of Food Composition and Analysis, 24:1-10.

74. Glew, R. H., Laabes, E. P., Presley, J. M., Schulze, J., Andrews, R., Wang, Y., Chang, Y. and Chuang, L. (2013). Fatty acid, amino acid, mineral and antioxidant content of acha (Digitaria exilis) grown on the Jos Plateau, Nigeria. International Journal of Nutrition and Metabolism, 5(1):1-8.

75. Ukim, C. I., Ojewola, G. S., \& Obun, C. O. (2013). Nutritive and replacement value of hungry rice, 'acha" (Digitaria exilis) grain for maize grain in broiler starter chicks. Global Journal of Agricultural Sciences, 12:55-61. 
76. Promchan, J., Gunther, D., Siripinyanond, A., \& Shiowatana, J. (2016). Elemental imaging and classifying rice grain by using laser ablation inductively coupled plasma mass spectrometry and linear discriminant analysis. Journal of Cereal Science, 71:198-203.

77. Moreira-Araújo, R. S., \& Brandāo, A. (2018). Foods produced with cowpea flour as a strategy to control iron deficiency anemia in children. In: Current Topics in Anemia. Jasmine Khan. IntechOpen, pp. 258-271, https://dx.doi.org/10.5772/ intechnopen69892.

78. Chesters, J. K. (1997). In: O’Dell, B. L. and Sunde, R. A. (Eds.). Handbook of nutritionally essential mineral elements, CRS Press, Taylor and Francis Group, LLC, Missouri, 185-203. 